\title{
Is there a determining factor that predicts mortality in patients with congenital diaphragmatic hernia?
}

\author{
Tansel Gunendi ${ }^{1}$, Basak Erginel ${ }^{1}$, Ercan Bastu ${ }^{2}$, Ibrahim Kalelioglu², Recep Has ${ }^{2}$, Feryal Gun Soysal ${ }^{1}$, \\ Erbug Keskin ${ }^{1}$, Aladdin Celik ${ }^{1}$, Tansu Salman ${ }^{1}$ \\ ${ }^{1}$ Department of Pediatric Surgery, Medical Faculty, Istanbul University, Istanbul, Turkey \\ ${ }^{2}$ Division of Perinatology, Department of Obstetrics and Gynecology, Medical Faculty, Istanbul University, Istanbul, Turkey
}

Kardiochirurgia i Torakochirurgia Polska 2017; 14 (3): 149-153

\begin{abstract}
Aim: This study was designed to investigate the factors affecting the prognosis in neonates with congenital diaphragmatic hernia $(\mathrm{CDH})$ who were treated in our clinic. These factors included prenatal lung-head ratio (LHR), prenatal stomach and liver presence in the thorax, blood gases in the first $24 \mathrm{~h}$ and the modified ventilation index (MVI).

Material and methods: The study was carried out retrospectively in 30 neonates with prenatally diagnosed left $\mathrm{CDH}$ who were treated in our clinic between January 2007 and 2013. Data were collected, evaluated, and statistically analyzed for gender, birth weight, gestational age, prenatal LHR, prenatal presence of stomach and liver in the thorax, postnatal initial blood gases in the first $24 \mathrm{~h}$ and MVI.

Results: The median LHR for non-survivors was 1.49 and for survivors 1.51. No statistically significant difference in LHR was detected between survivors and non-survivors. In 19 neonates, prenatal ultrasonography (USG) revealed intrathoracic stomach, and 9 of these infants died. Intrathoracic liver was seen in 15 neonates, and 9 of these died. A statistically significant difference was not found between survivors and non-survivors in the intrathoracic liver or intrathoracic stomach neonates. A comparison between the non-survivors and survivors showed a median $\mathrm{pH}$ value of 7.10 in non-survivors and 7.24 in survivors $(p=0.002)$. The median $\mathrm{PaCO}_{2}$ value was $69.4 \mathrm{~mm} \mathrm{Hg}$ in non-survivors and $51.9 \mathrm{~mm} \mathrm{Hg}$ in survivors ( $p=0.01)$. There were statistically significant differences in $\mathrm{pH}$ and $\mathrm{PaCO}_{2}$ values. The median value of MVI was 33 in survivors and 100 in non-survivors. There was a statistically significant difference between overall non-survivors and survivors in the MVI value $(p<0.05)$.

Conclusions: Based on the findings, postnatal $\mathrm{pH}$, and $\mathrm{PaCO}_{2}$ and $M V I$ values are favorable prognostic factors in $\mathrm{CDH}$ in our selected group of patients.
\end{abstract}

Key words: congenital diaphragmatic hernia, prenatal diagnosis, prognostic factors.

\section{Streszczenie}

Cel: Badanie przeprowadzono, aby ocenić czynniki wpływające na rokowanie u noworodków z wrodzoną przepukliną przeponową (CDH) leczonych w klinice autorów. Czynniki te obejmowaty prenatalny współczynnik płuco-głowa (LHR), obecność żołądka i wątroby w klatce piersiowej, gazometrię krwi w pierwszych 24 godzinach oraz zmodyfikowany indeks wentylacji (MVI).

Materiat i metody: Do badania włączono retrospektywnie grupę 30 noworodków, u których prenatalnie stwierdzono lewostronną $\mathrm{CDH}$, leczonych w klinice autorów pomiędzy styczniem 2007 a 2013 r. Zebrano, oceniono i poddano analizie statystycznej dane dotyczące płci, masy urodzeniowej, wieku ciążowego, przedurodzeniowej wartości LHR, przedurodzeniowej obecności żołądka i wątroby w klatce piersiowej, wyników pourodzeniowej gazometrii w pierwszych 24 godzinach oraz wartości MVI.

Wyniki: Średnia wartość LHR u noworodków, które nie przeżyły, wyniosła 1,49, a u ocalałych 1,51. Nie stwierdzono statystycznie znamiennej różnicy w zakresie wartości LHR pomiędzy tymi grupami. W prenatalnym badaniu ultrasonograficznym wykryto obecność żołądka w klatce piersiowej u 19 noworodków - 9 z nich zmarło. Obecność wątroby zaobserwowano u 15 noworodków - 9 zmarło. Nie wykazano statystycznie znamiennej różnicy pomiędzy noworodkami ocalałymi i zmarłymi w zakresie obecności wątroby lub żołądka w klatce piersiowej. Porównanie pacjentów zmarłych z ocalałymi wykazało medianę wartości pH na poziomie 7,10 w grupie zmarłych i 7,24 w grupie ocalałych $(p=0,002)$. Mediana wartości $\mathrm{PaCO}_{2}$ wyniosła 69,4 mm Hg w grupie zmarłych i 51,9 mm Hg w grupie ocalałych $(p=0,01)$. Różnice pomiędzy wartościami $\mathrm{pH} \mathrm{i} \mathrm{PaCO}_{2}$ były znamienne statystycznie. Również znamienna statystycznie $(p<0,05)$ była różnica pomiędzy średnią wartością MVI u noworodków ocalałych $(\mathrm{MVI}=33)$ a wartością tego parametru u noworodków zmarłych (MVI = 100).

Wnioski: Na podstawie wyników można stwierdzić, że pourodzeniowe wartości $\mathrm{pH}, \mathrm{PaCO}_{2}$ i MVI stanowią użyteczne czynniki rokownicze $w$ omawianej grupie pacjentów.

Słowa kluczowe: wrodzona przepuklina przeponowa, rozpoznanie prenatalne, czynniki rokownicze.

Address for correspondence: Basak Erginel MD, Department of Pediatric Surgery, Medical Faculty, Istanbul University, Yildirim Oguz Goker Cad. 5. Gazeteciler Sitesi, C-1, no: 36, Akatlar-Beşiktaş, 34000 Istanbul, Turkey, phone: +90 532 6464787, e-mail: basakerginel@hotmail.com Received: 27.12.2016, accepted: 17.07.2017. 


\section{Introduction}

Congenital diaphragmatic hernia $(\mathrm{CDH})$ is a rare congenital anomaly causing severe respiratory distress. In this abnormality, the abdominal organs enter the thorax through a diaphragmatic defect. Although it varies between $1 / 2000$ and $1 / 5000$, its incidence is believed to be higher due to stillbirths and terminations of pregnancy due to accompanying lethal anomalies. Factors such as pulmonary hypoplasia and pulmonary hypertension lead to high mortality and morbidity rates in babies born with this condition [1-3]. Hence, many factors have been proposed to explain the prognosis of the high mortality, including lung-heart ratio (LHR), presence of stomach or liver in the thorax, blood gases in the first $24 \mathrm{~h}$ and the modified ventilation index $(\mathrm{MVI})$. Because of the limited number of cases, no single factor alone has been proven to determine the prognosis.

\section{Aim}

In this study, we aimed to evaluate whether factors such as prenatal LHR, presence of stomach or liver in the thorax, blood gases in the first $24 \mathrm{~h}$ and $\mathrm{MVI}$ in infants who were treated in our clinic contributed to the prognosis in prenatally diagnosed $\mathrm{CDH}$.

\section{Material and methods}

This study was carried out retrospectively in the Istanbul Faculty of Medicine, Department of Pediatric Surgery with 30 isolated CDH patients seen between January 2007 and December 2013. All the neonates were diagnosed and followed up in the Division of Perinatology of the University prenatally and transferred to the Department of Pediatric Surgery. All of the lesions were left sided. The associated anomalies were bilateral grade II hydronephrosis in 1 patient, cleft palate in 1 patient, patent ductus arteriosus (PDA) in 1 patient, atrial septal defect (ASD) in 2 patients, patent foramen ovale (PFO) in 1 patient, and PDA and ventricular septal defect (VSD) in 1 patient.

All of the patients underwent prenatal two-dimensional ultrasonography and had a prenatal diagnosis of $\mathrm{CDH}$. The LHR was measured prenatally by two-dimensional ultrasonography; the two longest perpendicular diameters of the contralateral lung are multiplied and this is divided by head circumference (in $\mathrm{mm}$ ) [4]. All diagnoses were made prenatally at 24-26 weeks of gestational age and LHR was measured at the same time. The deliveries were all sectio. The prematurity rate was 5/30 (16.7\%).

The time of the surgery was $2.5 \pm 1.1$ days. We did not use a patch in any of the cases.

Twenty-one newborns had normal chromosomal analysis, 8 patients refused analysis, and 1 patient had $\mathrm{t}(1,5)$ (p21;p14) on analysis. The mean time of newborns stay at the hospital was $22.2 \pm 18.8$ days. We do not have extracorporeal membrane oxygenation (ECMO). The presence of the stomach or liver in the thoracic region was also noted during ultrasonography. Upon delivery, the newborns were transferred to our neonatal intensive care unit (NICU). Con- ventional ventilation was used in all cases. Following hemodynamic and respiratory stabilization $\left(\mathrm{pH}>7.45, \mathrm{PaCO}_{2}\right.$ $<60 \mathrm{~mm} \mathrm{Hg}$, and $\mathrm{PaO}_{2}>45 \mathrm{~mm} \mathrm{Hg}$ ), the patients underwent the operation. Each prenatally diagnosed neonate's sex, gestational weight, gestational age, LHR, presence of stomach or liver in thorax, blood gases in the first $24 \mathrm{~h}$ and $M V I$ were recorded. The MVI is a parameter defined in determining the prognosis of neonates with $\mathrm{CDH}$ under mechanical ventilation [5]. It is calculated from the factors of $\mathrm{PIP}$, ventilatory frequency, and $\mathrm{PCO}_{2}\left(\mathrm{PIP} \times \mathrm{PCO}_{2} \times\right.$ ventilation frequency/1000).

\section{Statistical analysis}

Descriptive statistical methods were used to analyze the results for the groups. Kolmogorov-Smirnov and Shapiro-Wilk tests were used for the normality analysis. ANOVA and $t$-test methods were used to compare the groups and to ensure that a normal distribution was found. The Kruskal-Wallis test was used for the variance analysis, and the Mann-Whitney $U$ test was used to compare the groups that did not have a normal distribution. Ninety-five percent was accepted as the confidence interval, and a $p$-value $\leq 0.05$ was considered significant for the analysis.

\section{Results}

Of the 30 neonates enrolled in the study, 20 (66.6\%) were male and 10 (33.3\%) were female, mean gestational weight was $2900 \pm 471 \mathrm{~g}$, and mean gestational age was $37.8 \pm 1.6$ weeks.

Data were grouped and analyzed according to mortality. Overall mortality was 14 (46.6\%). Fourteen of the 30 neonates died. Eleven (55\%) of them were male and 3 (33\%) were female. Seven neonates died before surgery and 23 neonates underwent operations. The mean defect area in our patients was $3 \times 4 \mathrm{~cm}$ and no patch was used in any of our patients. Of these 23 patients, 7 died post-operatively.

Among 13 patients with LHR < 1.4, 7 (53\%) neonates were lost. Among 17 neonates whose LHR was > 1.4, again 7 (29\%) neonates were lost. The median LHR in the overall group was 1.6. (For non-survivors it was 1.49 and for survivors 1.51.) No statistical significance was detected among the groups according to LHR.

The stomachs were present in the thoraxes of 19 (63.3\%) patients, $9(47 \%)$ of whom died. The livers were present in the thoraxes of 15 (50\%) neonates, and 9 (60\%) of them died. A statistically significant difference was not found between survivors and non-survivors in the intrathoracic liver or intrathoracic stomach groups either (Tab. I).

For the evaluation of the prognostic values of LHR, $\mathrm{pH}$, $\mathrm{PaCO}_{2}, \mathrm{PaO}_{2}$, base excess in the extracellular fluid compartment (BEecf), and $\mathrm{CHCO}_{3}$, the neonates were grouped as total non-survivors and survivors. From perinatal delivery until discharge, 14 neonates were lost and 16 neonates survived. A comparison between the non-survivors and survivors showed a median $\mathrm{pH}$ value of 7.10 in non-survivors and 7.24 in survivors $(p=0.002)$. The median $\mathrm{PaCO}_{2}$ value was $69.4 \mathrm{~mm} \mathrm{Hg}$ in non-survivors and $51.9 \mathrm{~mm} \mathrm{Hg}$ in sur- 
Tab. I. Distribution of demographic data according to mortality $(n=30)$

\begin{tabular}{lcccccc} 
Parameter & $\begin{array}{c}\text { Male } \\
(n=20)\end{array}$ & $\begin{array}{c}\text { Female } \\
(n=10)\end{array}$ & $\begin{array}{c}\text { LHR }<1.4 \\
(n=13)\end{array}$ & $\begin{array}{c}\text { LHR }>1.4 \\
(n=17)\end{array}$ & $\begin{array}{c}\text { Stomach } \\
\text { in thorax }(n=19)\end{array}$ & $\begin{array}{c}\text { Liver in thorax } \\
(n=15)\end{array}$ \\
Total & $11 / 20$ & $3 / 10$ & $7 / 13$ & $7 / 17$ & $9 / 19$ & $9 / 15$ \\
\hline Exitus & $(55 \%)$ & $(33 \%)$ & $(53 \%)$ & $(41 \%)$ & $(47 \%)$ & $(60 \%)$ \\
\hline
\end{tabular}

vivors $(p=0.01)$. There were statistically significant differences in $\mathrm{pH}$ and $\mathrm{PaCO}_{2}$ values (Tab. II).

For investigating the prognostic value of $\mathrm{MVI}$, the data were compared between overall non-survivors and survivors. The median MVI value in non-survivors was 100 (32167), whereas in survivors it was 33 (19-63). Only 1 neonate was lost with $\mathrm{MVI}<37$; however, all the neonates were lost with $M V I>80$. There was a statistically significant difference between overall non-survivors and survivors in the MVI value $(p<0.05)$.

To determine a threshold value for $\mathrm{MVI}$, an receiver operating characteristic (ROC) curve was generated. The MVI threshold value was 37 with a sensitivity of $92 \%$ and specificity of $82 \%$ (Fig. 1).

\section{Discussion}

The search for prognostic factors affecting the $\mathrm{CDH}$ prognosis has been a long process. It may be that a sole factor will not be singled out to determine the survival for this congenital anomaly, but rather, a combination of several factors will have to be taken into account [6].

The LHR calculated by prenatal ultrasound was first described by Metkus et al. in 1996. Fifty-five neonates were reviewed in this retrospective study, and it was reported that all neonates were lost when LHR was $<0.6$, and $61 \%$ of neonates survived when LHR was 0.6-1.30. Survival reached $100 \%$ when LHR was > 1.4 with the aid of ECMO and conventional therapies [7]. Following this report and many others, mortality and morbidity were shown to decline when LHR was < 1.0 [8]. Based on this information, experimental studies with fetal tracheal occlusion are continuing in North America and Europe [9]. However, because there are a limited number of cases and every clinic has unique criteria for selecting patients, standardized protocols for LHR have not been established. In our study, no statistically significant difference in LHR was observed between survivors and non-survivors. However, 4 out of 6 of our patients with LHR below 1.0 were lost. This provides a clue about this parameter, which should be investigated within a larger study population.

The presence of the stomach in the thorax is another prognostic factor that has been proposed in survival. Burge et al. reported high mortality in their study investigating the prognostic effect of stomach position; that is, when the stomach was in the thorax, mortality was greater, but when the stomach was in the abdomen, survival was $100 \%$ [10]. Hatch et al. reported survival of $93 \%$ when the stomach was below the diaphragma and $29 \%$ when it was in the thorax [11]. In a multicenter study from Japan, Usui et al. defined intrathoracic stomach as when more than
Tab. II. Comparison between survivors and non-survivors

\begin{tabular}{lccc} 
Parameter & $\begin{array}{c}\text { Non-survivors }(n=14) \\
\text { Median }\end{array}$ & $\begin{array}{c}\text { Survivors }(n=16) \\
\text { Median }\end{array}$ & P-value \\
$\mathrm{LHR}$ & 1.49 & 1.51 & 0.498 \\
\hline $\mathrm{pH}$ & 7.10 & 7.24 & $0.002^{*}$ \\
\hline $\mathrm{PaCO}_{2}$ & 69.4 & 51.9 & $0.01^{*}$ \\
\hline $\mathrm{PaO}_{2}$ & 40.9 & 51.3 & 0.064 \\
\hline $\mathrm{BEecf}^{\mathrm{CHCO}}$ & -7.5 & -4.8 & 0.101 \\
\hline $\mathrm{CHCH}_{3}$ & 14.3 & 18.3 & 0.131 \\
\hline
\end{tabular}

Mann-Whitney U Test. ${ }^{*} P<0.05$.

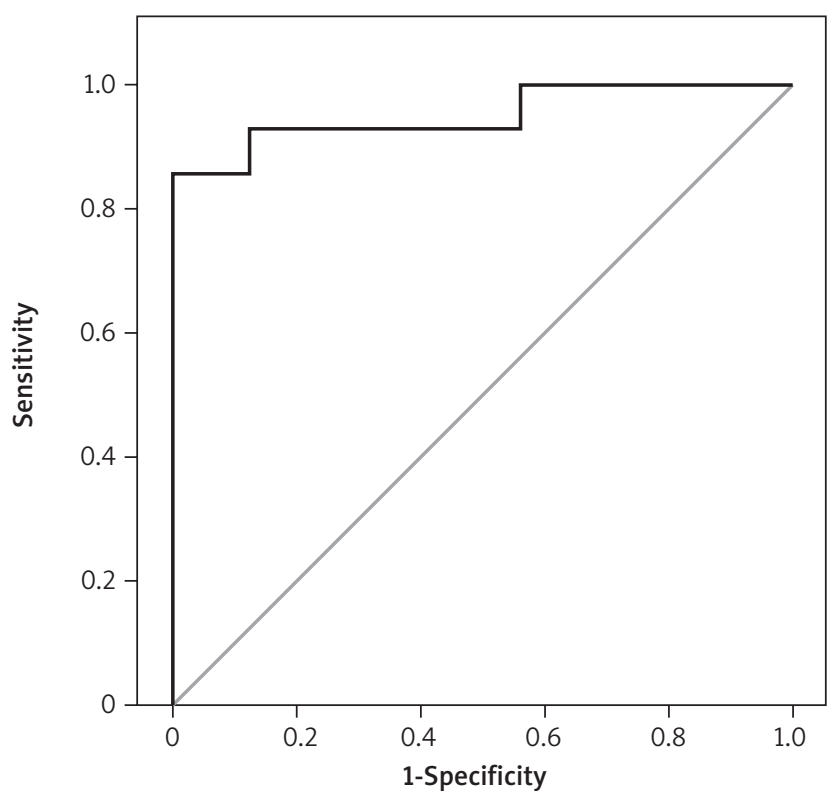

Fig. 1. Receiver operating characteristic curve for modified ventilation index $(\mathrm{AUC}=0.95 ; p=0.042)$

half of the stomach was herniated into the thorax. Of the 117 neonates enrolled in their study, the stomach was found in the thoraxes of $70 \%$ of the neonates in the high-risk group, $25.7 \%$ in the medium-risk group, and $4.2 \%$ of neonates in the low-risk group. Survival was reported at $20 \%$ in the high-risk group, $74.3 \%$ in the medium-risk group, and $100 \%$ in the low-risk group [12]. In our study, the stomach was present in the thoraxes of $63.3 \%$ of the neonates, and survival was $53 \%$, which is lower than in the previous series. Nine neonates were lost in the intrathoracic stomach group and five neonates were lost in the intra-abdominal stomach group. The presence of the stomach in the thorax did not relate to survival in our study. This result is not concordant with the literature, which was attributed to pulmonary hypertension. 
The presence of the liver in the thorax is a factor for determining prognosis and planning fetal interventions. In the antenatal $\mathrm{CDH}$ registry group, Jani et al. reported 86 intra thoracic livers out of 184 neonates [13]. In the same study, previous reports were also evaluated. The study of Metkus et al. included 38 neonates of which $80 \%$ had intrathoracic livers, while Heling et al. reported a rate of $64 \%$ for intrathoracic livers in 22 neonates. Victoria et al. conducted a study with 85 neonates, wherein 51 (60\%) had intrathoracic livers and 23 were lost with a $45 \%$ survival rate [14]. In their meta-analysis, Mullasery et al. evaluated 21 studies that were published in the Medline and Embase databases. These studies focused on the presence of the liver in thorax. There were 407 livers detected in thoraxes. Of the 407 neonates, 222 were lost and 185 survived; overall survival was $45.4 \%$ [15]. In our study, 9 of 15 neonates with intrathoracic livers were lost and 5 of 15 neonates with intra-abdominal livers were lost; survival was $40 \%$ for these patients. A statistically significant difference between the groups was not revealed; therefore, the presence of the liver in the thorax could not be shown as a prognostic factor, contradicting the current literature. Pulmonary hypertension was the main reason for this discrepancy.

Blood gases in the first $24 \mathrm{~h}$ have been proposed as a prognostic factor in many studies since Boix-Ochoa presented their report in 1974 [16]. Early era studies showed an association with $\mathrm{pH}, \mathrm{PaCO}_{2}$, and mortality between survivors and non-survivors. Low $\mathrm{PaCO}_{2}$ and high $\mathrm{PaO}_{2}$ levels that were either previously normal or corrected by mechanical ventilation have been found to be related to a good prognosis. On the other hand, despite mechanical ventilation, persistently high levels of $\mathrm{PaCO}_{2}$ were related to a poor prognosis. Blood gases have also been investigated for timing of surgery when pre-operative preparations were deemed necessary. Gentili et al. reported that $\mathrm{pH}>7.35$ with $\mathrm{PaCO}_{2}$ $<55 \mathrm{~mm} \mathrm{Hg}$ is a valid indicator for pre-surgical stabilization and surgical intervention [17]. Haricharan et al. stated that hypercapnia in initial blood gases is related to high mortality [18]. Similarly, Hoffman et al. reported a survival rate of $27 \%$ when $\mathrm{PaCO}_{2}<60 \mathrm{~mm} \mathrm{Hg}$, but all the patients were lost when $\mathrm{PaCO}_{2}>70 \mathrm{~mm} \mathrm{Hg}$ [19]. Neonates who were lost in our study had median $\mathrm{pH}$ at 7.1 and median $\mathrm{PaCO}_{2}$ at $69.4 \mathrm{~mm} \mathrm{Hg}$, whereas survivors had median $\mathrm{pH}$ at 7.24 and median $\mathrm{PaCO}_{2}$ at $51.9 \mathrm{~mm} \mathrm{Hg}$. Low pH and high $\mathrm{PaCO}_{2}$ levels between survivors and non-survivors had statistical significance, consistent with previous reports.

The $\mathrm{MVI}$ is a parameter that relates $\mathrm{PaCO}_{2}$ to peak inspiratory pressure in mechanically ventilated patients. Norden et al. reported their results of a study associating pre-operative $\mathrm{PaCO}_{2}$ values and ventilatory indices obtained in the first $24 \mathrm{~h}$ in 90 neonates. They showed that the MVI threshold value must be 40 for survival [20]. When the MVI is $<40$, they predicted the survival rate at $91 \%$ with a sensitivity of $94 \%$ and specificity of $85 \%$. Dimitriou et al. studied the blood gases and MVI values by calculating the lung area to determine the prognosis and MVI threshold. They observed an average of 49 in the good prognosis group [21]. Ilce and
Celayir revealed similar values in their study with $30 \mathrm{CDH}$ patients. Of the 30 patients, the mean MVI value of the survivors was 38.8, but the non-survivors' mean MVI value was 114.3 [5]. In our study, median MVI value for survivors was 33 and for the non-survivors was 100 . We found a threshold value of 37 for MVI for predicting mortality. The MVI values were $<40$ in $92 \%$ of our neonates, which were all lost. All neonates with $\mathrm{MVI}>80$, as suggested by previous reports, were lost.

This study has limitations due to its retrospective nature and limited number of cases. The limited number of patients did not permit two analyses missing for a prediction study, i.e. a multivariate analysis and analysis of AUC/ predictive value. Another limitation of the study is that the protocol of these patients is unique for our study; this prediction model pertains to this center and neonatal protocol, so it may not be applicable elsewhere. However, one advantage of our study is that there are no missing values in any of the patients. The mentioned parameters are evaluated in all of the patients.

\section{Conclusions}

In light of these findings, $\mathrm{pH}, \mathrm{PaCO}_{2}$ levels and $\mathrm{MVI}$ have a positive predictive value in prognosis. LHR, liver, and/or stomach presence in the thorax could not be related to prognosis. Future research is necessary to reveal the outcome of the prognostic factors in isolated $\mathrm{CDH}$ as well as long-term morbidity.

\section{Disclosure}

Authors report no conflict of interest.

\section{References}

1. Arensman RM, Bambini DA. Congenital diaphragmatic hernia and eventration. In: Pediatric Surgery. Ashcraft KW et al. (eds). WB Saunders Company, Philadelphia 2000; 300-317

2. Ba'ath ME, Jesudason EC, Losty PD. How useful is the lung-to-head ratio in predicting outcome in the fetus with congenital diaphragmatic hernia? A systematic review and meta-analysis. Ultrasound Obstet Gynecol 2007; 30: 897-906.

3. Bahlmann F, Merz E, Hallermann C, Stopfkuchen H, Kramer W, Hofmann M. Congenital diaphragmatic hernia: ultrasonic measurement of fetal lungs to predict pulmonary hypoplasia. Ultrasound Obstet Gynecol 1999; 14: 162168.

4. Ruano R, Lazar DA, Cass DL, Zamora IJ, Lee TC, Cassady Cl, Mehollin-Ray A, Welty S, Fernandes CJ, Haeri S, Belfort MA, Olutoye OO. Fetal lung volume and quantification of liver herniation by magnetic resonance imaging in isolated congenital diaphragmatic hernia. Ultrasound Obstet Gynecol 2014; 43: 662-669.

5. Ilçe Z, Celayir S. Modified ventilation index $(M V I)$ in newborns with congenital diaphragmatic hernia. Indian Pediatr 2003; 40: 920.

6. Pediatric Surgery. $6^{\text {th }}$ edn. Grosfeld JL, Fonkalsrud EW, Coran AG (eds.). Mosby-Year Book Inc., St. Louis, 2006; 931-946.

7. Metkus AP, Filly RA, Stringer MD, Harrison MR, Adzick NS. Sonographic predictors of survival in fetal diaphragmatic hernia. J Pediatr Surg 1996; 31: 148-151.

8. Harrison MR, Keller RL, Hawgood SB, Kitterman JA, Sandberg PL, Farmer DL, Lee H, Filly RA, Farrell JA, Albanese CT. A randomized trial of fetal endoscopic tracheal occlusion for severe fetal congenital diaphragmatic hernia. N Engl J Med 2003; 349: 1916-1924.

9. Jani JC, Nicolaides KH. Fetal surgery for severe congenital diaphragmatic hernia? Ultrasound Obstet Gynecol 2012; 39: 7-9. 
10. Burge DM, Atwell JD, Freeman NV. Could the stomach site help predict outcome in babies with left sided congenital diaphragmatic hernia diagnosed antenatally? J Pediatr Surg 1989; 24: 567-569.

11. Hatch EL Jr, Kendall J, Blumhagen J. Stomach position as an in utero predic tor of neonatal outcome in left-sided diaphragmatic hernia. J Pediatr Surg 1992; 27: 778-779.

12. Usui N, Kitano Y, Okuyama H, Saito M, Masumoto K, Morikawa N, Takayasu H, Nakamura T, Hayashi S, Kawataki M, Ishikawa H, Nose K, Inamura N, Sago $\mathrm{H}$. Prenatal risk stratification for isolated congenital diaphragmatic hernia: results of a Japanese multicenter study. J Pediatr Surg 2011; 46: 1873-1880.

13. Jani J, Keller RL, Benachi A, Nicolaides KH, Favre R, Gratacos E, Laudy J, Eisenberg V, Eggink A, Vaast P, Deprest J; Antenatal-CDH-Registry Group. Prenatal prediction of survival in isolated left-sided diaphragmatic hernia. Ultrasound Obstet Gynecol 2006; 27: 18-22.

14. Victoria T, Bebbington MW, Danzer E, Flake AW, Johnson MP, Dinan D, Scott Adzick N, Hendrick HL. Use of magnetic resonance imaging in prenatal prognosis of the fetus with isolated left congenital diaphragmatic hernia. Prenatal Diag 2012; 32: 715-723.

15. Mullasery D, Ba'ath ME, Jesudason EC, Losty PD. Value of liver herniation in prediction of outcome in fetal congenital diaphragmatic hernia: a sys- tematic review and meta-analysis. Ultrasound Obstet Gynecol 2010; 35: 609-614.

16. Boix-Ochoa J, Peguero G, Seijo G, Natal A, Canals J. Acid-base balance and blood gases in prognosis and therapy of congenital diaphragmatic hernia. J Pediatr Surg 1974; 9: 49-57.

17. Gentili A, Giuntoli L, Bacchi Reggiani ML, Masciopinto F, Lima M, Baroncini S. Neonatal congenital diaphragmatic hernia: respiratory and blood-gas derived indices in choosing surgical timing. Minerva Anestesiol 2012; 78: 1117-1125.

18. Haricharan R, Barnhart DC, Cheng H, Delzell E. Identifying neonates at a very high risk for mortality among children with congenital diaphragmatic hernia managed with extracorporeal membrane oxygenation. J Pediatr Surg 2009; 44: 87-93.

19. Hoffman SB, Massaro AN, Gingalewski C, Short BL. Predictors of survival in congenital diaphragmatic hernia patients requiring extracorporeal membrane oxygenation: CNMC 15-year experience. J Perinatol 2010; 30: 546552.

20. Norden MA, Butt W, McDougall P. Predictors of survival for infants with congenital diaphragmatic hernia. J Pediatr Surg 1994; 29: 1442-1446.

21. Dimitriou G, Greenough A, Davenport, Nicolaides K. Prediction of outcome by computer-assisted analysis of lung area on the chest radiograph of in fants with congenital diaphragmatic hernia. J Ped Surg 2000; 35: 489-493. 